J. Perinat. Med. 6(1978) 39

\section{The secretion of catecholamines in newborn babies with special reference to fetal distress}

\author{
T. Nakai, R. Yamada
}

Department of Clinical Pathology and Metabolism, Dokkyo University School of Medicine, Mibu Town, Tochigi Prefecture, Japan

\section{Preface}

Little is known about the blood concentrations of catecholamines in the fetus. For some years it has been known that catecholamines can be detected in the adrenal glands of the fetus.

WEST et al. [14] reported that noradrenaline is predominant over adrenaline in fetal ages in contrast with the pattern of adult ages, and that the former is also detected in larger amounts in the extramedullary chromaffine tissues, which are the so-called "paraaortic tissues". In WEST's studies, approximately $90 \%$ of the catecholamines in both the adrenals and the paraaortic tissues were found to occur as noradrenaline before 70 days of postnatal life. On the contrary,GREENBERG and LIND [7] reported that adrenaline and noradrenaline were found in approximately equal amounts in the adrenal glands of early fetuses, when determined by fluorescent techniques.

Accordingly, it was considered of interest to study the pattern of blood catecholamine concentrations in fetal ages and compare it with the pattern in adult ages.

It has also been reported by several workers that asphyxia in experimental animals causes striking increases in secretions by the adrenal medulla. Thus, one might logically expect an increased production of catecholamines in fetal distress. Indeed, this is precisely one of the major problems being faced by the obstetrician or the paediatrician.

\section{Curriculum vitae}

TOSHIAKI NAKAI, was born in 1940. Study of Medicine in Tokyo University. 1968 Medical doctor. For 9 years Clinical assistant at Department of Obstetrics and Gynecology, Tokyo University: Since 1974, associate professor of Clinical Pathology and Metabolism at the Dokkyo University School of Medicine, Mibu Town, Tochigi Prefecture, Japan. Main fields of interests: Catecholamines, fetal endocrinology, perinatal diagnosis.

\section{Methods}

For the purpose of this study two groups of infants were selected. Group 1 comprised 30 normal fullterm infants born in a satisfactory state without episode of fetal distress. Their mothers had no personal, or family history suggestive of endocrine or metabolic diseases, and their pregnancy was uncomplicated. The infant's weight varied from $2,800-3,800 \mathrm{~g}$, the average being $3,300 \mathrm{~g}$, and their APGAR scores were between eight and ten. Group 2 included asphyxial infants whose APGAR scores were between five and seven. The mothers of both groups had no complications before or during pregnancy. Blood samples were drawn. 
immediately after delivery from the umbilical artery of their mother.

Four newborn babies out of 15 distressed ones required umbilical catheter insertion. Blood samples were drawn from the umbilical catheter $3,13,8$, 48 hours after birth, respectively. The blood samples were collected into bottles each containing $5 \mathrm{ml}$ of a $2 \%$ sodium fluoride and $3 \%$ sodium thiosulphate solution as a preservative and anticoagulant. The plasma was separated as soon as possible after the sampling, and if subsequent purification could not be effected immediately, it was stored at freezing temperatures overnight. Catecholamines were estimated by the trihydroxyindole method [13]. The essence of the procedure for simultaneous fluorometric determinations of adrenaline and noradrenaline in the blood is as follows: adrenaline and noradrenaline are isolated from the plasma by adsorption on alumina in a weak alkaline solution and then by elution with acetic acid. They are oxidized to adrenochrome and noradrenochrome with manganese dioxide, respectively.

They are rearranged with sodium hydroxide to adrenolutine and noradrenolutine which, on irradiation with the ultraviolet light, give yellowish green fluorescences. The fluorescences were measured with a photofluorometer (the model UM-S; Shimadzu Seisakusho, Kyoto).

\section{Results}

\subsection{Catecholamine concentrations in normal infants}

Catecholamine concentrations in the plasma of infants and their mothers, measured in unit of $\mu \mathrm{g} / 1$, are shown in Table 1 . Adrenaline levels in the plasma of normal infants were shown to be higher than those in the plasma of their mothers. Especially, adrenaline levels in the umbilical artery were more than twice as high as those in the maternal femoral artery $(P<0.01)$. Twenty-six mothers had a mean adrenaline level of $5.4 \mu \mathrm{g} / 1$ in the plasma, with a standard deviation of $3.9 \mu \mathrm{g} / 1$; while the mean adrenaline concentrations in the umbilical vein and artery were $7.0 \mu \mathrm{g} / 1$ and $11.2 \mu \mathrm{g} / 1$ with standard deviations of $5.8 \mu \mathrm{g} / 1$ and $6.3 \mu \mathrm{g} / 1$, respectively (Tab. I).
Noradrenaline levels in thirty cases are also shown in Table 1. There is an apparent increase in noradrenaline concentration in the umbilical artery by more than twice, when compared with the concentration in the mother's femoral artery $(\mathrm{P}<0.01)$. Twenty-six mothers had a mean noradrenaline level of $9.8 \pm 4.1 \mu \mathrm{g} / 1$ in the plasma, while the mean noradrenaline concentration in the umbilical vein was $16.3 \mu \mathrm{g} / 1$, with a standard deviation of $7.6 \mu \mathrm{g} / 1$, and the mean noradrenaline concentration in the umbilical artery was $20.2 \mu \mathrm{g} / 1$, with a standard deviation of $8.6 \mu \mathrm{g} / 1$. Catecholamine concentrations in the cord blood, especially those in the umbilical artery, were shown to be higher than those in the maternal artery.

\subsection{Catecholamine concentrations in asphyxial infants}

The catecholamine values in fifteen asphyxial infants with APGAR scores between four and seven can be compared with those in normal full-term infants. The values are shown in Tab. II.

In all cases but one, blood levels of noradrenaline were found to have been elevated, though blood levels of adrenaline had been unchanged or slightly elevated. The mean concentrations of noradrenaline and adrenaline were $6.96 \pm 4.36 \mu \mathrm{g} / 1$ and 46.1 $\pm 16.35 \mu \mathrm{g} / \mathrm{l}$, respectively, It is clear that the noradrenaline concentrations in the asphyxial infants were almost twice as high as those in the normal infants, whereas no significant increase was detected in the concentration of adrenaline.

\subsection{Catecholamine concentrations in distressed newborns during neonatal period}

In all of the four distressed newborns, noradrenaline concentrations in the blood remained elevated for several hours after birth. The concentrations are given in Tab. III.

\section{Discussion}

In the normal group, adrenaline was found present in the umbilical vessels in considerably large amounts. Catecholamine concentrations in the umbilical vessels, especially those in the umbilical 
Tab. I. Catecholamine concentrations in normal babies and their mothers.

Code: $\mathbf{A}$, adrenaline; NA, noradrenaline.

\begin{tabular}{|c|c|c|c|c|c|c|}
\hline \multirow[t]{2}{*}{ No. of cases } & \multicolumn{2}{|l|}{ mother } & \multicolumn{4}{|l|}{ baby } \\
\hline & A & NA & $\mathbf{A}$ & NA & $\mathbf{A}$ & NA \\
\hline $\begin{array}{r}1 \\
2 \\
3 \\
4 \\
5 \\
6 \\
7 \\
8 \\
9 \\
10 \\
11 \\
12 \\
13 \\
14 \\
15 \\
16 \\
17 \\
18 \\
19 \\
20 \\
21 \\
22 \\
23 \\
24 \\
25 \\
26 \\
27 \\
28 \\
29 \\
30\end{array}$ & $\begin{array}{r}1.0 \\
5.2 \\
13.0 \\
5.2 \\
2.6 \\
2.7 \\
2.0 \\
8.0 \\
8.0 \\
1.7 \\
3.7 \\
2.5 \\
9.7 \\
0\end{array}$ & $\begin{array}{r}4.0 \\
18.2 \\
4.5 \\
14.5 \\
9.1 \\
17.1 \\
9.1 \\
3.5 \\
7.0 \\
6.1 \\
12.6 \\
9.1 \\
11.3 \\
3.8\end{array}$ & $\begin{array}{c}11.1 \\
9.3 \\
0 \\
1.2 \\
5.4 \\
0 \\
2.8 \\
23.8 \\
10.2 \\
6.5 \\
11.0 \\
4.3 \\
3.7 \\
17.2 \\
6.5 \\
0 \\
2.7 \\
3.7 \\
2.4 \\
1.3 \\
15.7 \\
15.5 \\
7.4 \\
0 \\
9.7 \\
6.5 \\
5.2 \\
10.3 \\
10.3\end{array}$ & $\begin{array}{r}9.8 \\
28.8 \\
16.5 \\
7.6 \\
10.2 \\
20.5 \\
19.6 \\
20.9 \\
22.6 \\
5.8 \\
19.4 \\
30.2 \\
13.0 \\
15.1 \\
5.8 \\
9.2 \\
9.5 \\
19.0 \\
13.3 \\
16.8 \\
22.8 \\
\\
22.6 \\
13.0 \\
26.1 \\
22.4 \\
0 \\
27.2 \\
18.1 \\
6.4\end{array}$ & $\begin{array}{c}2.7 \\
11.9 \\
10.7 \\
0 \\
12.9 \\
12.8 \\
\\
10.3 \\
7.8 \\
12.9 \\
20.6 \\
\\
14.1 \\
10.1 \\
12.9 \\
7.3 \\
4 \\
18.1 \\
10.4 \\
2.6 \\
\\
19.5 \\
\\
16.0 \\
26.0 \\
0 \\
15.6 \\
6.9 \\
13.4\end{array}$ & $\begin{array}{r}12.3 \\
27.8 \\
6.4 \\
22.6 \\
29.3 \\
22.7 \\
\\
9.1 \\
18.2 \\
13.2 \\
36.2 \\
\\
26.0 \\
20.2 \\
3.7 \\
26.4 \\
9.2 \\
30.3 \\
10.4 \\
18.2 \\
\\
22.9\end{array}$ \\
\hline
\end{tabular}

Tab. II. Catecholamine concentrations in distressed newborns and their mothers.

Code: A, adrenaline; NA, noradrenaline; n.d., not detectable

\begin{tabular}{|c|c|c|c|c|c|c|c|}
\hline \multirow[t]{3}{*}{ No. of cases } & \multirow[t]{3}{*}{ APGAR score } & \multirow{2}{*}{\multicolumn{2}{|c|}{ mother }} & \multicolumn{4}{|c|}{ newborns } \\
\hline & & & & \multicolumn{2}{|c|}{ umbilical vein } & \multicolumn{2}{|c|}{ umbilical artery } \\
\hline & & $\mathbf{A}$ & NA & $\mathbf{A}$ & NA & $\mathbf{A}$ & NA \\
\hline 1 & 4 & & & 14.0 & 45.3 & 19.5 & 50.9 \\
\hline 2 & 5 & & & n.d & 9.1 & n.d. & 22.6 \\
\hline 3 & 5 & & & & & 6.1 & 54.3 \\
\hline 4 & 5 & 5.2 & 4.5 & 11.0 & 9.8 & n.d. & 30.2 \\
\hline 5 & 5 & & & & & 4.7 & 37.1 \\
\hline 6 & 7 & 6.5 & 22.6 & 5.1 & 27.1 & 5.1 & 62.4 \\
\hline 7 & 6 & 0.0 & 22.0 & & & n.d. & 30.8 \\
\hline 8 & 6 & 2.7 & 13.7 & n.d. & 13.6 & 7.9 & 34.9 \\
\hline 9 & 6 & 3.8 & 13.4 & n.d. & 36.2 & 10.4 & 81.6 \\
\hline 10 & 7 & 8.61 & 10.6 & 12.9 & n.d. & 11.1 & 32.4 \\
\hline 11 & 7 & 2.7 & $14: 2$ & 2.9 & 5.4 & 8.7 & 60.4 \\
\hline 12 & 7 & 2.6 & 9.6 & 8.6 & 30.2 & 9.9 & 58.5 \\
\hline 13 & 7 & & & n.d. & 24.9 & n.d. & 13.6 \\
\hline 14 & 7 & & & 23.3 & 18.1 & 10.4 & 49.8 \\
\hline 15 & 7 & n.d. & 13.0 & n.d. & 18.2 & 15.4 & 72.0 \\
\hline
\end{tabular}

J. Perinat. Med. 6 (1978) 
Tab. III. Catecholamine concentrations in distressed neonates.

\begin{tabular}{|c|c|c|c|c|c|c|}
\hline $\begin{array}{l}\text { No. of } \\
\text { cases }\end{array}$ & & & & & $: 1$ & \\
\hline 1 & & & & 3 hours following delivery & $\begin{array}{l}\mathbf{A} \\
\text { NA }\end{array}$ & $\begin{array}{l}11 \\
26\end{array}$ \\
\hline 2 & at birth & $\begin{array}{l}\text { A } \\
\text { NA }\end{array}$ & $\begin{array}{r}8 \\
56\end{array}$ & 8 hours following delivery & $\begin{array}{l}\text { A } \\
\text { NA }\end{array}$ & $\begin{array}{r}8 \\
52\end{array}$ \\
\hline 3 & at birth & $\begin{array}{l}\text { A } \\
\text { NA }\end{array}$ & $\begin{array}{l}26 \\
52\end{array}$ & 13 hours following delivery & $\begin{array}{l}\text { A } \\
\text { NA }\end{array}$ & $\begin{array}{l}20 \\
72\end{array}$ \\
\hline 4 & at birth & $\begin{array}{l}\text { A } \\
\text { NA }\end{array}$ & $\begin{array}{l}11 \\
58\end{array}$ & 48 hours following delivery & $\begin{array}{l}\text { A } \\
\text { NA }\end{array}$ & $\begin{array}{l}11 \\
45\end{array}$ \\
\hline
\end{tabular}

artery, were found to be higher than those in the maternal artery. The differences in catecholamine concentrations strongly suggest the capability of the fetal adrenal medulla and sympathetic nervous system to secrete catecholamines in response to the stress of labor. It has been known for some years that catecholamines in the adrenals are detectable during the fetal life. WEST et al. [14] reported that the fetal adrenals contain little adrenaline, and that noradrenaline accounts for $90 \%$ of the catecholamines. GREENBERG and LIND [7], not in agreement with West's findings, discovered that noradrenaline and adrenaline are present in approximately equal amounts in the adrenal glands of fetuses. Our studies seem to support the latter's report since large amounts of adrenaline were detected in the umbilical artery. It has been well known that the pituitary-adrenocortical system plays an important role in the process of adaptation. Owing to this, many studies have been devoted to the mechanism of this endocrine system in fetuses and newborn infants. GEMZELL [5] has found a significant difference between the umbilical cord 17-hydroxycorticosteroids in normal vaginal delivery and those in delivery by caesarean section. Since caesarean section is considered easy delivery for the fetus, as compared to vaginal delivery-which is a strong stresser to the fetus delivered, the difference in the plasma 17-hydroxycorticosteroids mentioned above indicates the responsiveness of the fetal pituitaryadrenocortical system.

KAWAHARA [10] also found the same tendency between 17-hydroxycorticosteroids in normal vaginal delivery and those in delivery by forceps, suggesting that the application of forceps is a stronger stresser to the fetus than normal vaginal delivery. GRASSI and MANESCHI [6] estimated the eosinophil count immediately following normal vaginal delivery as 332 per $\mathrm{cm}^{3}$, and 37 per cent less after pathological delivery (210 eosinophils per $\mathrm{cm}^{3}$ ). LOPEZ and ACOSTA [12] found 331 eosinophils per $\mathrm{cm}^{3}$ in human newborns at birth by caesarean section, 178 in those by normal delivery, and only 39 in those by forceps delivery. Almost identical values, 332, 121 and 55 circulating eosinophils per $\mathrm{cm}^{3}$, were found by CHISCI and BELLORA [2] under similar conditions.

All the above-mentioned studies suggest the capability of the fetal and neonatal pituitary-adrenocortical system to respond to stressful stimulus. Thus, it seems likely that not only the fetal adrenal cortex but also the adrenal medulla responds to the stress of labor; and the newborn are able to adapt themselves to the new environment. In the asphyxial babies, a striking increase of noradrenaline secretion was found, and it seemed surprising that the adrenaline concentration in their blood was almost the same as that of the normal infants. It was also found that there is no difference between catecholamine concentrations in their mothers and those in mothers who delivered normal infants.

BRUNDIN [1] was the first to find the release of catecholamines by the fetal main paraaortic body of the rabbit. He showed that severe asphyxia elicited marked losses of catecholamines from the paraaortic bodies. HERVONEN and KORKALA [8] achieved similar results after exposure of the fetal paraganglia to lowered oxygen concentrations. By using perfusion techniques, they found a definite decrease in the intensity of the catecholaminespecific fluorescence in the paraganglia. 
COMLINE et al. [3] exhaustively studied the relation between changes in the composition of fetal blood and the release of catecholamines by the adrenal medulla during asphyxia in the fetal lamb. Great changes in the foetal blood $\mathrm{PO}_{2}, \mathrm{PCO}_{2}$, $\mathrm{pH}$ and lactic acid concentration occurred after induction of hypoxia. The adrenal medulla also reacted directly to asphyxia with a secretion which contained a high proportion of noradrenaline. This high proportion of noradrenaline continued to be secreted throughout the entire period of asphyxia and is the most distinguishing feature of the response of the foetal lamb to the asphyxia.

Although the reasons for the high proportion of noradrenaline secretion ramain unknown, the following surmise may be made: firstly, it may be attributed to the relatively high proportion of noradrenaline content in the fetal medullary chromaffine tissue $[14,7]$ and secondly, it may in part be due to the preponderance of the extramedullary chromaffine tissue over the medullary chromaffine tissue in the fetal life. A structual difference in development is reported to be present between the

\section{Summary}

Immediately after delivery, the plasma catecholamines were investigated in the femoral arterial blood of mothers and in the umbilical venous and arterial bloods of their infants. Catecholamines were estimated by the trihydroxyindole method. In the first group consisting of normal full-term infants, maternal levels of adrenaline and noradrenaline were $5.4 \pm 3.9 \mu \mathrm{g} / 1$ and $9.8 \pm 4.1 \mu \mathrm{g} / 1$, respectively. Umbilical venous levels of adrenaline and noradrenaline were $7.0 \pm 5.8 \mu \mathrm{g} / 1$ and $16.3 \pm 7.6 \mu \mathrm{g} / \mathrm{l}$; and umbilical arterial levels of adrenaline and noradrenaline were $11.2 \pm 6.3 \mu \mathrm{g} / 1$ and $20.2 \pm 8.6 \mu \mathrm{g} / 1$, respectively. Catecholamines in the cord blood, especially those in the umbilical artery, were shown to be higher than those in the maternal artery. This might be attributed to many factors, but the most probable factor is the excitation of medullary chromaffine tissue and the extramedullary chromaffine tissue. The former is scanty and immature in the fetal life, and the latter develops earlier than the adrenal medulla $[14,4,9]$. This extramedullary chromaffine tissue appears to be a source of higher noradrenaline output in fetal distress.

During the neonatal period, an elevated noradrenaline secretion was detected in all four distressed babies. Apart from the blood concentrations, urinary concentrations of noradrenaline and adrenaline were determined in six distressed and sixteen normal newborns [11]. Noradrenaline output in the urine was found to be elevated in the group of distressed newborn infants. On the contrary, no statistically significant difference in adrenaline output was found between the two groups. This high concentration of urinary noradrenaline found in the distressed group might result from the activation of the chromaffine cell system in response to metabolic acidosis and in good agreement with our data found in distressed newborn infants.

Keywords: Catecholamine secretion in newborns, fetal distress.

\section{Zusammenfassung}

Die Katecholamin-Sekretion des Neugeboṛenen unter Berücksichtigung fetaler Gefahrenzustände.

Unmittelbar nach der Entbindung wurden die PlasmaKatecholamine im femoralen Arterienblut von Müttern und sowohl im umbilikalen venösen als auch im arteriellen Blut der Neugeborenen untersucht. Die Katecholamine wurden anhand der Trihydroxyindolin-Methode bestimmt. In der ersten, aus 30 normalen, voll ausgereiften Neuge- the adrenal medulla during parturition. These results suggest that the fetal medulla and sympathetic nervous system already begin to secrete catecholamines before birth. In the second group which comprised distressed infants with APGAR scores between five and seven, noradrenaline concentrations were found to be significantly elevated except in one infant, although adrenaline concentrations were unchanged or slightly elevated. This response may be due to the direct effects of hypoxia on the noradrenaline cells. The distressed newborn babies during the neonatal period also had noradrenaline concentrations which were more than twice as high as those of normal newborns. Thus, noradrenaline was found to be the dominating amine discharged by the fetal and neonatal chromaffine tissues during distress.

J. Perinat. Med. 6 (1978)

borenen bestehenden Gruppe betrugen die Adrenalin und Noradrenalin-Spiegel:

\section{Adrenalin Noradrenalin}

Mutter Arterie

Fet Nabelvene

Fet Nabelarterie

$$
\begin{array}{rrr}
5,4 \pm 3,9 & 9,8 \pm 4,1 & \mu \mathrm{g} / \mathrm{ml} \\
7,0 \pm 5,8 & 16,3 \pm 7,6 & \mu \mathrm{g} / \mathrm{ml} \\
11,2 \pm 6,3 & 20,2 \pm 8,6 & \mu \mathrm{g} / \mathrm{ml}
\end{array}
$$


Die Katecholamine erwiesen sich im Nabelschnurblut, insbesondere in der Nabelarterie, höher als in der Arterie der Mutter. Dies kann auf eine Reihe von Faktoren zurückzuführen sein; am ehesten kommt jedoch die Reizung des Nebennierenmarks während der Entbindung in Frage.

Das läßt darauf schließen, daß das fetale Nebennierenmark und das sympathische Nervensystem bereits vor der Geburt Ketecholamine ausscheiden. In der zweiten Gruppe, die 15 gefährdete Neugeborene mit APGAR-Punkten zwischen fünf und sieben umfaßte, wurden mit einer Ausnahme signifikant erhöhte Noradrenalin-Konzentrationen

Schlüsselwörter: fetale Gefahrenzustände, Katecholamine. angetroffen, obwohl die Adrenalin-Konzentrationen unverändert oder nur geringfügig erhöht waren. Diese Reaktion könnte auf den unmittelbaren Einfluß der Hypoxie auf die Noradrenalin-Zellen zurückzuführen sein. Bei den gefährdeten Neugeborenen waren auch in der Neonatalzeit Noradrenalin-Konzentrationen festzustellen, die zweimal so hoch waren wie bei normalen Neugeborenen. Offenbar ist Noradrenalin das im Gefahrenzustand vorherrschende, von den chromaffinen Geweben des Feten und des Neugeborenen ausgeschiedene Amin.

\section{Résumé}

Sécrétion de catécholamines chez les nouveaux-nés avec référence spéciale au distress foetal.

Aussitôt après l'accouchement, les catécholamines du plasma ont été étudiées dans le sang artériel fémoral des mères et dans la veine ombilicale et les sangs artériels de leurs nourrissons. Les catécholamines ont été déterminées par la. méthode à la trihydroxyindole. Dans le premier groupe, consistant de 30 nourrissons normaux nés à terme, les niveaux d'adrénaline et de noradrénaline chez les mères étaient respectivement de $5.4 \pm 3.9 \mu \mathrm{g} / \mathrm{L}$ et de $9.8 \pm 4.1 \mu \mathrm{g} / \mathrm{L}$. Les niveaux veineuses ombilicales d'adrénaline et de noradrénaline étaient respectivement de $7.0 \pm 5.8 \mu \mathrm{g} /$ Let de $16.3 \pm 7.6 \mu \mathrm{g} / \mathrm{L}$; les niveaux d'adrénaline et de noradrénaline dans l'artère ombilicale étaient respectivement de $11.2 \pm 6.3 \mu \mathrm{g} / \mathrm{L}$ et $20.2 \pm 8.6 \mu \mathrm{g} / \mathrm{L}$. Les catécholamines dans le sang du cordon, en particulier celles dans l'artère ombilique, ont été supérieures à celles de l'artère de la mère. On peut attribuer ceci à plusieurs facteurs, mais le plus probable est l'excitation de la moelle adrénale pendant l'accouchement. Ces résultats suggèrent que la moelle fétale et le système nerveux sympathique commencent déjà à secréter des catécholamines avant la naissance. Dans le second groupe, composé d'enfants $(N=15)$ non normaux avec des points APGAR entre cinq et sept toutes les concentrations de noradrénaline sauf une ont été trouvées élevées de façon significative, bien que les concentrations d'adrénaline n'avaient pas changé ou aient été légèrement élevées. Cette réponse peut être due aux effets directs de l'hypoxie sur les cellules de noradrénaline. Les nouveaux-nés non normaux ont eu ausși pendant leur période néonatale des concentrations de noradrénaline deux fois plus élevées que celles des nouveaux-nés normaux. On a ainsi trouvé que la noradrénaline était l'amine dominante secrétée par le tissu chromạffine fétal et néonatal pendant l'épuisement.

Mots-clés: distress foetal, sécrétion de catécholamines chez les nouveaux-nés.

\section{Bibliography}

[1] BRUNDIN, T.: Studies on the preaortal paraganglia of newborn rabbits. Acta Physiol. Scand. 290 (1966) 70

[2] CHISCI, R., M. BELLORA: Various aspects of adrenal cortex function in the newborn in relation to the stress of birth. Minerva. Ginec. 13 (1961) 1236

[3] COMLINE, R. S., I. A. SILVER., M. SILVER: Factors responsible for the stimulation of the adrenal medulla during asphyxia in the foetal lamb. J. Physiol. 178 (1965) 211

[4] COUPLANS, R. E.: The prenatal development of the abdominal paraaortic bodies in man. J. Anat. 86 (1952) 357

[5] GEMZELL, C. A.: Blood levels of 17-hydroxycorticosteroids in normal pregnancy. J. Clin. Endocr. Metab. 13 (1953) 898

[6] GRASSI, G., M. MANESCHI: L'attivita ipofisocorticosurrenalica durante il periods neonatale. Quand. Clin. Obst. Ginec. 9 (1954) 553
[7] GREENBERG, R. E., J. LIND: Catecholamines in tissues of the human fetus. Pediatrics Calif. 27 (1961) 904

[8] HERVONEN, A., O. KORKALA: The effect of hypoxia on the catecholamine content of human fetal abdominal paraganglia and adrenal medulla. Acta Obst. Gynec. Scand. 51 (1972) 17

[9] HUNTER, R. B., A. R. MACGREGOR, D. M. SHEPHERD, G. B. WEST: The organs of Zuckerkandl and the suprarenal medulla. J. Physiol. Lond. 118 (1952) $11 \mathrm{p}$

[10] KAWAHARA, H.: Plasma levels of 17-hydroxycorticosteroids in umbilical cord blood, with special reference to variations of the level between $A$. umbilicalis and V. umbilicalis. J. Clin. Endocr. Metab. 18 (1958) 325

[11] KUDO, T., J. F. ROUX: Catecholamine excretion in the urine of term pregnant women and the newborn. J. Reprod. Med. 4 (1970) 237 
[12] LOPEZ, F. R. J., E. M. ACOSTA: Alcuni aspetti della funzione corticosurrenale nei processi della generazione. Rass, Int. Clin. Terapia. 37 (1957) 429

[13] LUND, A.: Simultaneous fluorometric determinations of adrenaline and noradrenaline in blood. Acta Pharmacol. 6 (1950) 137
[14] WEST, G. B., D. M. SHEPHERD, R. B. HUNTER, A. R. MCGREGOR: The function of the organs of Zuckerkandl. Clin. Sci. 12 (1953) 317

Received and accepted July 14, 1977.

Toshiaki Nakai, M.D.

Department of Clinical Pathology

Dokkyo University School of Medicine Mibu Town, Tochigi Prefecture, Japan 